\title{
Tributes to David Sanders
}

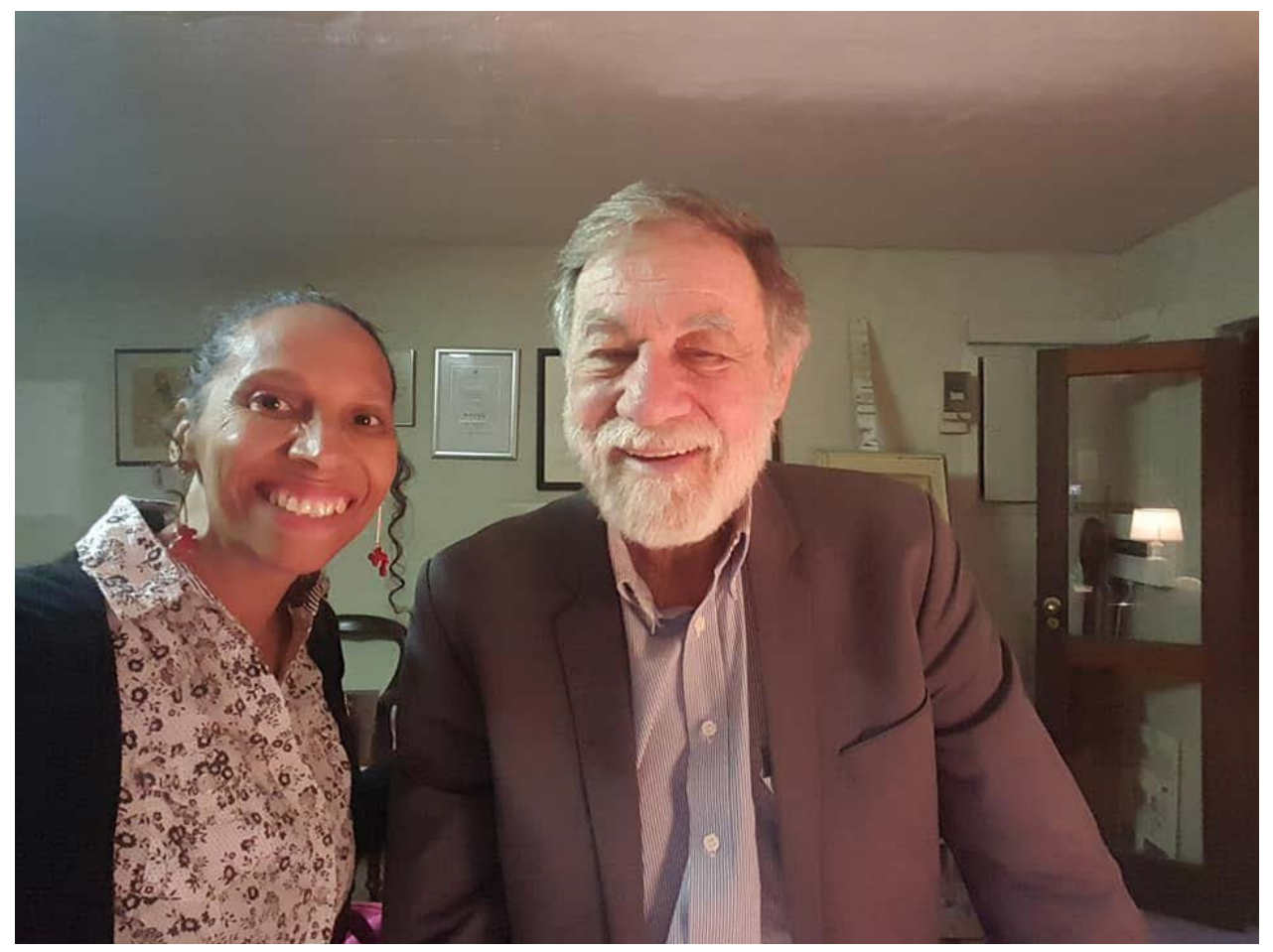

Chantell Witten writes:

It is with great sadness that I make this submission. I met Prof Sanders in 1999 while completing my MSc Nutrition at the University of the Western Cape. Prof Sanders introduced us to Primary Health Care and health inequity. He was not big in physical structure but he was a towering giant in the field of public health nutrition. In his lectures, he was passionate and engaging in taking one on a journey of discovery of all the things that were wrong in our health and social systems.

In 2001, I would join Prof Sanders as a young upstart in public health nutrition. The running joke between us was that David saved me from the sugar industry--from where I had joined the School of Public Health. It really wasn't such a joke if I reflect on where I am now and what my career path could have been instead.

In fact, David was a visionary; he was ahead of the curve and many of us did not fully understand him. But now, we will fully grasp our loss and the impact that it will have in South Africa on the struggle against great inequity, on our research, and our collective ownership of what we should and could do better as academics, as activists and as a people. 
David was a brilliant mind, a tireless champion for the marginalized and an astute scholar, bringing research to bear on the lives of people who lived realities of social injustice. Prof David Sanders will also be remembered for his wry sense of humor, his questioning mind and his will to do more. His legacy will live on through the many of us who have passed through his lectures, his teaching, his being. Until we have social justice and health equity for all, David's voice will remind us that we have not done enough! Aluta Continua! Rest well, Prof Sanders.

Ted Greiner writes:

In January 1983 I made a presentation at a UNICEF/journalist meeting on the economic and social aspects of breastfeeding in Harare. David Sanders come up to me afterwards, and our friendship began. On a return visit a few years later, he kindly had me over to his home for more in depth discussions. He was considering moving to South Africa where he had been invited to start a new health institute.

Later, from his new position as head of the School of Public Health at the University of the Western Cape, his department and mine at Uppsala University entered into a multiyear research and teaching collaboration supported by the Swedish Agency for Research Cooperation (SAREC).

David and I also worked together within the context of the now defunct NGO/Civil Society constituency of the UN System Standing Committee on Nutrition. His was one of the strongest voices for bottom up, community-based approaches, avoiding the magic bullets increasingly in favour among nutrition donors. All of his work was incisive, passionate, and in defence of a just and more equal world. He is sadly missed.

Elisabetta Recine writes:

I first met David Sanders many years ago when we were planning an annual SCN meeting in Brazil. At that time, the SCN had working groups and an NGO/civil society constituency he belonged to. He had a real interest in talking about my country, which is rare in international forums. I was impressed how well he knew our reality. We met again many times. During World Nutrition Rio we walked around the city and I always had fun with his peculiar humor and admired his commitment to life. People like him who combine sensitivity with commitment are lacking.

Regina Keith writes:

David Sanders was a rare gem who valued listening to the voices of others. He spent his life trying to ensure the voices of marginalised populations were heard in relation to health policy and planning cycles. 
He was a founding member of the People's Health Movement and an active member of the World Public Health Nutrition association. His books (including Struggle for Health and Questioning the Solution) help to shine a light on global systems that help to prevent health for all. His activist leadership has led to more people supporting the achievement of the Alma Ata vision of health for all.

As a small token of appreciation for his vision and leadership in Global Public Health and Nutrition, Cara International Consulting Ltd. will be offering an annual $£ 100$ book token prize. The prize will be selected by the Directors of Cara International Consulting Ltd and will be awarded to the MSc Global Public Health Nutrition thesis, at the University of Westminster (https://www.westminster.ac.uk/nutrition-courses/201920/september/full-time/global-public-health-nutrition-msc), that best reflects the Alma Ata Principles.

The award will be presented at the November Graduating ceremony and will be known as the Sanders Alma Ata award. For more information contact r.keith@westminster.ac.uk 